\title{
Phosphorus stress of phytoplankton in the Taiwan Strait determined by bulk and single-cell alkaline phosphatase activity assays
}

\author{
Linjian $\mathrm{Ou}^{1}{ }^{1}$ Bangqin Huang ${ }^{1, *}$, Lizhen Lin ${ }^{1}$, Huasheng Hong ${ }^{1}$, Fang Zhang ${ }^{2}$, \\ Zhaozhang Chen ${ }^{1}$
}

\author{
${ }^{1}$ State Key Laboratory of Marine Environmental Science and Environmental Science Research Center, Xiamen University, \\ 361005 Xiamen, Fujian, PR China \\ ${ }^{2}$ Fujian Institute of Oceanography, 361012 Xiamen, Fujian, PR China
}

\begin{abstract}
Phosphorus stress of marine phytoplankton was determined by using both bulk and single-cell alkaline phosphatase activity (APA) assays during the summer (July to August 2004) and winter (March 2005) along 2 transects (A and B) in the Taiwan Strait. During the summer of 2004, time-series variations in APA were monitored on a daily basis for $6 \mathrm{~d}$ along a third transect (F). Results showed that surface APA along Transects A and B ranged between 1.14 and $7.30 \mathrm{nmol} \mathrm{l}^{-1} \mathrm{~h}^{-1}$, respectively with a mean of $4.43 \mathrm{nmol} \mathrm{l}^{-1} \mathrm{~h}^{-1}$. High soluble APA contribution indicated that phytoplankton in this area suffered long-term phosphorus (P) stress. Percentages of enzyme-labeled fluorescence (ELF-labeled) representative phytoplankton increased with bulk APA during the time-series investigation and compared favorably with phosphate concentration. Dinoflagellates had high percentages of ELF labeling during both seasons, suggesting that they were under severe P-stress. The predominant dinoflagellates were Skeletonema costatum, Chaetoceros spp., Asterionellopsis glacialis, Thalassionema nitzschioides and Pseudo-nitzschia spp. During the summer, A. glacialis, T. nitzschioides and Pseudo-nitzschia spp. were labeled with ELF, which meant they were also P-stressed during that time of year. Percentages of algal cells labeled with ELF were lower during the winter, suggesting that the relatively high, soluble reactive phosphorus supply softened phytoplankton P-stress in this period. Species such as Rhizosolenia spp. and T. nitzschioides were for some reason still P-stressed during the winter. Both field and lab data suggested that bulk and single-cell APA should be used together to provide comprehensive assessment of phytoplankton P-stress from the community level to the individual taxon level in natural phytoplankton communities.
\end{abstract}

KEY WORDS: Phytoplankton - Phosphorus stress - Alkaline phosphatase - Enzyme-labeled fluorescence · Taiwan Strait

Resale or republication not permitted without written consent of the publisher

\section{INTRODUCTION}

In oligotrophic oceans, the spatial and temporal distribution of phytoplankton is tightly controlled by the availability of nutrients. Although nitrogen is widely considered to be the major limiting nutrient in marine environments, it is well known that phosphorus (P) might play an important role in controlling primary production in a number of both coastal and openocean areas such as the Mediterranean Sea (Krom et al. 1991, Thingstad et al. 2005), the Sargasso Sea (Michaels et al. 1996), the northern Red Sea (Li et al.
1998) and the northern and western Atlantic Ocean (Wu et al. 2000, Sañudo-Wilhelmy et al. 2004).

Soluble non-reactive phosphorus (SNP) comprises a significant proportion of the total phosphorus (Wu et al. 2000). In the coastal oceans, the SNP pool generally represents 0 to $50 \%$ of the total dissolved phosphorus (TDP) pool; whereas in the open ocean, the SNP pool can be as great as $75 \%$ (Karl \& Yanagi 1997, BenitezNelson 2000). Consequently, the cycling of SNP might potentially control $\mathrm{P}$ availability and affect production of the natural phytoplankton communities (Sebastián et al. 2004b). This hypothesis has led to emphasis on 
the role of extracellular phosphatase and the investigation of bioavailability of various $\mathrm{P}$ compounds to natural communities (Cembella et al. 1984b, Ammerman \& Azam 1991, Björkman \& Karl 1994, Huang \& Hong 1999, Bruckmeier et al. 2005, Huang et al. 2005).

Alkaline phosphatase (AP) is the best characterized and probably the major extracellular enzyme induced by phytoplankton when the concentration of inorganic P drops (Healey \& Hendzel 1979, Cembella et al. 1984a). It is widely used as a potential diagnostic marker for P-status of phytoplankton (Healey \& Hendzel 1979, González-Gil et al. 1998, Hoppe 2003). Many methods have been widely used to measure alkaline phosphatase activity (APA) in natural communities (Cembella et al. 1984b, Li et al. 1998, Sebastián et al. 2004b, Bruckmeier et al. 2005), fluorometric and colormetric techniques (Bentzen et al. 1992, GonzálezGil et al. 1998).

The traditional methods of detecting the P-status of natural phytoplankton communities use bulk seawater samples ('bulk assay'), and separate classes of planktonic organisms through size-fraction filtration (Jansson 1976, Nausch 1998, Hoppe 2003). Therefore, the bulk assay does not provide P-status information at the individual taxon level (Dyhrman \& Palenik 1999). There is a need to develop approaches for monitoring phytoplankton physiology at the single-cell (individual) level to gain insight concerning the effects of nutrient status on primary production (Scanlan et al. 1997, Dyhrman et al. 2002).

A new single-cell APA assay is now being used to characterize the specific in situ nutrient physiology of phytoplankton (González-Gil et al. 1998, Rengefors et al. 2003, Lomas et al. 2004). The single-cell APA is detected using enzyme-labeled fluorescence (ELF), which was developed by González-Gil et al. (1998) for clonal cultured phytoplankton and by Rengefors et al. (2001) for natural freshwater phytoplankton. The AP on the cell surface reacts with the soluble ELF substrate product: 2-(5' -chloro-2' -phosphoryloxyphenyl)-6chloro-4- $\left({ }^{3} \mathrm{H}\right)$-quina zolinone (Molecular Probes) to produce an insoluble fluorescent precipitate at the site of the enzyme activity. The resulting yellow-green fluorescence can be detected by epifluorescent microscopy. With this single-cell ELF method, APA can be examined at the individual taxon level within the natural phytoplankton communities, and P-status between classes or even between individual cells in the same species can be determined (González-Gil et al. 1998, Dyhrman \& Palenik 1999, Rengefors et al. 2003).
The Taiwan Strait is a channel on the broad continental shelf between the East China Sea and the South China Sea in which there is a water flow between the 2 seas (see Fig. 1). The Taiwan Strait is mostly less than $100 \mathrm{~m}$ deep with irregular bottom topography. The climate is affected by subtropical monsoons, which come from the southwest during the summer and from the northeast during the winter. The strait demonstrates a distinct 'narrow pipe effect' which is due to its NE-SW aspect and to the mountains along both coasts (Hong et al. 1991, Liang 1997). Several currents such as the Zhejiang-Fujian Coastal Current, the Strait Warm Current and the intruding Kuroshio branch Current affect the water of this region (Hong et al. 1991). However, upwelling is the main source of $\mathrm{P}$ in the study area during the summer due to the low estuarine output of phosphate (Wu et al. 1997). Previous studies showed that low phosphate concentrations and high N:P ratios limited phytoplankton growth in the Taiwan Strait and the adjacent Xiamen Bay (Hong \& Huang 1995, Wu et al. 1997).

In our study, the P-status of marine phytoplankton was determined by using bulk and single-cell APA assays during the summer (July to August 2004) and winter (March 2005) along 2 transects (A, B) in the Taiwan Strait. During the summer field cruise only, a $6 \mathrm{~d}$ time-series survey of APA was carried out during which bulk and single-cell APA were assayed at several stations along a third transect $(F)$. The objectives of this study were to evaluate whether the phytoplankton community in the Taiwan Strait was under P-stress and to determine any seasonal variations and differences among algal species.

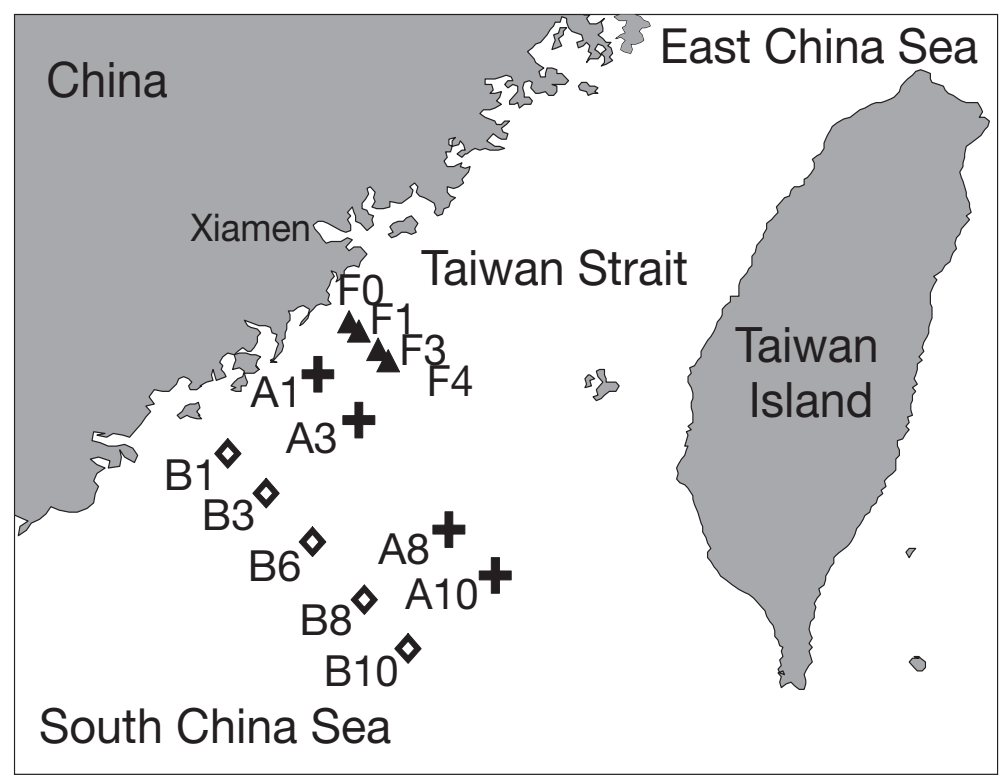

Fig. 1. Sampling stations in the Taiwan Strait 


\section{MATERIALS AND METHODS}

Sampling. Field cruises were carried out using the RV 'Yan Ping 2' from 30 July to 6 August 2004 and 15 to 17 March 2005. Water samples were taken only from the surface layer (1 m depth) (Fig. 1). All 3 transects (A, B and $F$ ) were included during the summer cruise, while only Transects A and B, and Stn F1 on Transect F were sampled during the winter cruise. The exception was Stn B10, which could not be sampled during the winter due to the weather. In addition, time-series surveys were performed by daily visits at Stns F0 to F4 along Transect F only during 1 to 6 August 2004. Water samples were collected using 2.51 Niskin bottles on a rosette sampler attached to a CTD set. As soon as the rosette had been taken on-board, the water was first sampled for dissolved oxygen (DO), then for nutrients and finally for biological parameters.

Hydrological parameters. A Sea-Bird 19 CTD was used to measure the water temperature, salinity, density and fluorescence.

Chemical parameters. The determination of DO in seawater was based on the method of Strickland \& Parsons (1968). Nitrite, nitrate + nitrite, soluble reactive phosphorus (SRP) and reactive silicate were determined colorimetrically using a flow injection analyzer (Tri-223 autoanalyzer) (Murphy \& Riley 1962, Armstrong et al. 1967, Pai et al. 1991). Ammonium was analyzed manually according to Parsons (1984). Dissolved inorganic nitrogen (DIN) was calculated as nitrate + nitrite + ammonium. TDP was measured based on Menzel \& Corwin (1965). SNP content was calculated by determining the difference between TDP and SRP, only during the summer. SRP, DIN and reactive silicate measurements was conducted on-board immediately following sample collection, whereas TDP samples were stored at $-20^{\circ} \mathrm{C}$ and analyzed at the laboratory on land following the cruise.

Chlorophyll a. Chl a was determined by analysis of fluorescence (Parsons et al. 1984), with the modification that the volume of seawater sampled was 150 to $300 \mathrm{ml}$, depending on the chl a concentration. Measurements were conducted in vitro in a Shimadzu (RF-5301PC) spectrofluorometer with the excitation and emission wavelengths set at $430 \mathrm{~nm}$ and $670 \mathrm{~nm}$, respectively.

Bulk alkaline phosphatase activity (APA). Bulk APA was assayed only during the summer. All seawater samples were first filtered through a $120 \mu \mathrm{m}$ filter to remove zooplankton. Three fractions of enzyme activity were distinguished according to Hoppe (2003). APA in the $0.2 \mu \mathrm{m}$ filtrate was regarded as soluble APA; APA contributed by organisms of the 0.2 to $3 \mu \mathrm{m}$ size (mainly bacteria) and calculated as the difference between APA of the 0.2 and $3 \mu \mathrm{m}$ filtrates; APA of particles $>3 \mu \mathrm{m}$ (mainly phytoplankton) and calculated as the difference between APA for the whole sample and that of the $3 \mu \mathrm{m}$ filtrate. Fluorescence of APA was determined as the release of 3-0-methylfluorescein from 3-0-methylfluorescein phosphate (MFP) (Sigma) with the excitation and emission wavelengths set at $435 \mathrm{~nm}$ and $520 \mathrm{~nm}$, respectively (Perry 1972, Healey \& Henzel 1979). One $\mathrm{ml}$ of 3-0-methylfluorescein phosphate $\left(1 \mathrm{mg} \mathrm{l}^{-1}\right)$ in Tris buffer with $\mathrm{pH} 8.72$ was added to $9 \mathrm{ml}$ of water sample, giving a final concentration of substrate as $0.3 \mu \mathrm{mol} \mathrm{l}^{-1}$. Samples were tested in replicate in the dark and at in situ temperatures for $1 \mathrm{~h}$. Calibration was performed with standard solutions of 3-0methylfluorescein in the range of 0.01 to $0.74 \mu \mathrm{mol} \mathrm{l}^{-1}$. Control blanks consisted of sterilized surface water. APA was expressed as nmol of MFP released $\mathrm{l}^{-1} \mathrm{~h}^{-1}$.

Single-cell ELF labeling. To assess the P-status of individual cells, single-cell ELF labeling was performed during both cruises. Approximately 5 to $10 \mathrm{l}$ surface seawater (according to the phytoplankton biomass) was concentrated using $10 \mu \mathrm{m}$ meshes and resuspended. The concentrated samples were processed for ELF labeling by centrifuging for $5 \mathrm{~min}$ at $4000 \times \mathrm{g}$. The supernatant was discarded and the cell pellets were transferred to a $1.5 \mathrm{ml}$ microfuge tube. We then proceeded according to Dyhrman et al. (1999). The pellets were incubated for $30 \mathrm{~min}$ with $1 \mathrm{ml}$ of $70 \%$ ethanol. The tubes were centrifuged $2 \mathrm{~min}$ at $3000 \times g$, and the supernatant was aspirated. A mixture of $5 \mu \mathrm{l}$ of ELF reagent (Molecular Probes) and $95 \mu \mathrm{l} 0.22 \mu \mathrm{m}$ filtered sterile in situ seawater was added to the pellets, and the cells were incubated for a further $30 \mathrm{~min}$ at room temperature in the dark. Incubation was followed by rinsing 3 times using sterile seawater to remove residual ELF substrate. Samples were stored in $100 \mu \mathrm{l}$ sterile seawater in the dark at $4{ }^{\circ} \mathrm{C}$ until analysis by epifluorescent microscopy. The sample was analyzed under a glass slide with mounting media from the ELF Phosphatase Detection Kit (Molecular Probes) and observed under a Zeiss epifluorescent microscopy with a DAPI (4'6'-diamidino-2-phenyl-indole) filter and a $100 \mathrm{~W}$ mercury lamp. All the samples were counted using standard light (Tungsten lamp) alternated with mercury light to check for ELF activity. The observed cells were divided into 2 groups on the basis of presence or absence of ELF precipitates. Percentage of ELF labeling for a given taxon was determined as the fraction of fluorescent-labeled cells relative to the total number of cells counted, as an index of algal sensitivity to P-stress for each season.

Variations single-cell APA in batch culture. To verify the feasibility of single-cell ELF assay in the field, 4 phytoplankton species were chosen. These included 2 dominant diatoms, Skeletonema costatum and Asterionellopsis glacialis, and 2 dinoflagellates, Prorocen- 
trum donghaiense and Alexandrium catenella, from the study area. Based on $\mathrm{f} / 2$ culture medium, algal cultures saturated with $\mathrm{P}$ were grown in $5 \mathrm{l}$ flasks with an initial phosphate concentration of approx. $2 \mu \mathrm{mol} \mathrm{l}^{-1}$. Percentages of cells labeled with ELF and the cellular enzyme sites were detected using a Zeiss epifluorescent microscope and a Leica confocal microscope (MRC1024), respectively. Bulk APA assays were also carried out to compare with the APA of single cells.

Data analysis. The statistical significance of differences in environmental parameters and APA was evaluated using Tukey's studentized range test. Correlations between APA and environmental variables were determined by linear regression. All tests were performed using the software SPSS 13.0.

\section{RESULTS}

\section{Environmental parameters of the study area}

The distribution of temperature, salinity, SRP and chl a along Transects A and B of the study area (Fig. 1) during the summer and winter cruises is shown in Fig. 2. Mean sea surface temperature (SST) during the summer $28.19 \pm 1.45^{\circ} \mathrm{C}$ and was significantly $(\mathrm{p}<0.01)$ higher than during the winter (mean $17.80 \pm 3.88^{\circ} \mathrm{C}$ ) (Fig 2A). Salinity changed little $(\mathrm{p}>0.05)$ between the summer and the winter cruises (Fig 2B).

During the summer cruise, SRP concentrations fluctuated between values below the detection limit of 0.10 and $0.23 \mu \mathrm{mol} \mathrm{l}^{-1}$. Surface SRP during the winter was significantly $(p<0.05)$ higher than during the summer, with highest values of 0.60 and $0.52 \mu \mathrm{mol} \mathrm{l}^{-1}$ at the nearshore Stns A1 and A3 (Fig. 2C). DIN concentration decreased with the distance from the shore during both seasons, and DIN during the winter was higher (mean $0.59 \pm 0.36 \mu \mathrm{mol} \mathrm{l}^{-1}$ ) than during the summer (mean $\left.0.35 \pm 0.50 \mu \mathrm{mol} \mathrm{l}^{-1}\right)(\mathrm{p}>0.05)$. SNP at most stations was below the detection limit of $0.10 \mu \mathrm{mol} \mathrm{l}^{-1}$ during the summer. The only values collected were from the nearshore Stn A1 $\left(0.19 \mu \mathrm{mol} \mathrm{l}^{-1}\right)$ and the offshore Stn B10 $\left(0.11 \mu^{-10 l} \mathrm{l}^{-1}\right)$ during the summer cruise.

$\mathrm{Chl}$ a was heterogeneous along Transects A and B during the summer, fluctuating from $0.2 \mathrm{mg} \mathrm{m}^{-3}$ to $3.6 \mathrm{mg} \mathrm{m}^{-3}$. Chl a was much lower during the winter (mean $0.29 \pm 0.04 \mathrm{mg} \mathrm{m}^{-3}$ ) (Fig. 2D).

Transect $\mathrm{F}$ had a lower temperature $\left(25.56 \pm 0.61^{\circ} \mathrm{C}\right)$ and a higher salinity $(34.08 \pm 0.09 \%)$ than Transects $A$ and B $(p<0.01)$ on 1 August 2004. Time-series monitoring along Transect F showed that, generally, SST increased, while salinity and chl a decreased during the survey. SRP concentrations were high during the first 3 to $4 \mathrm{~d}$, but decreased markedly thereafter (Fig. 3).
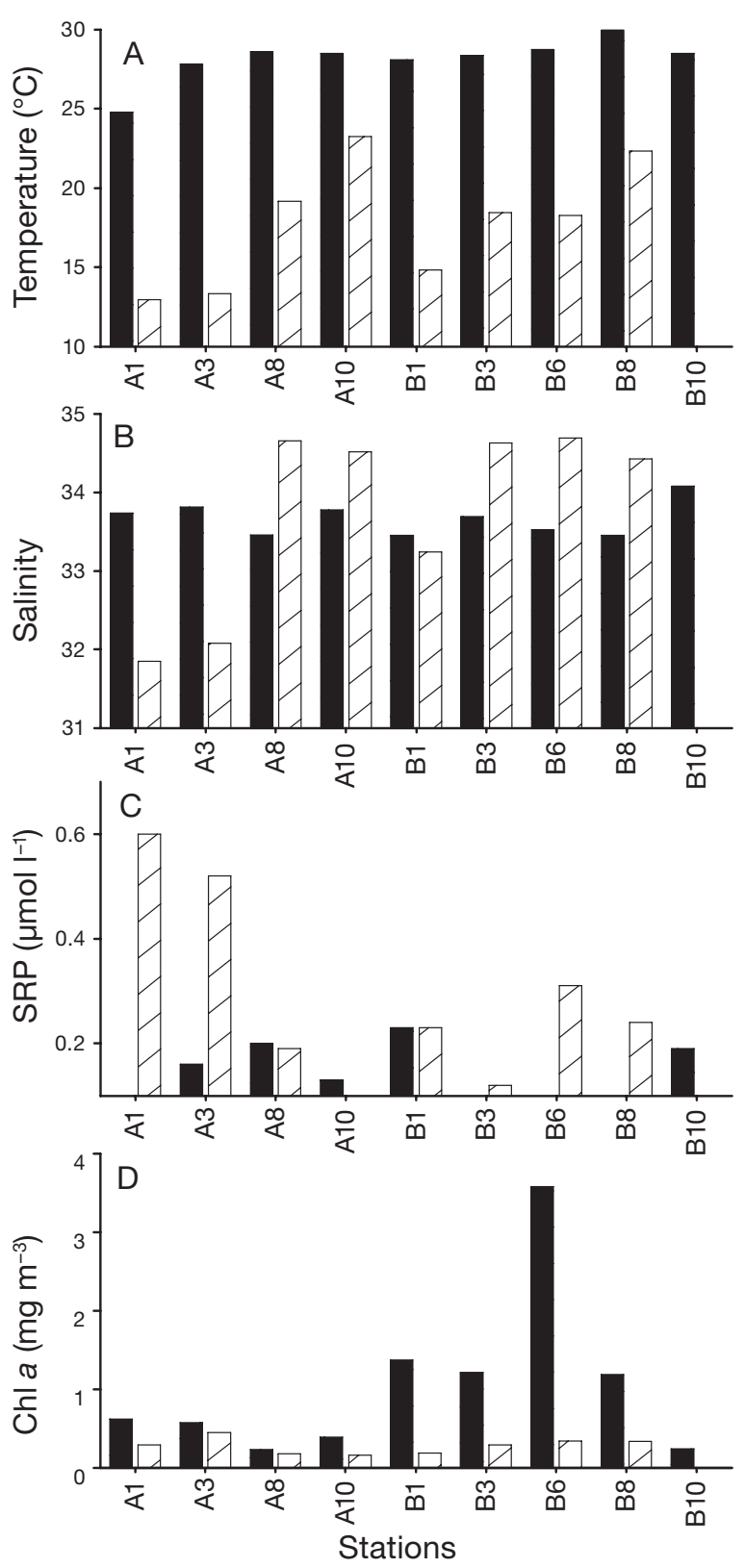

Fig. 2. Mean surface water (A) temperatures, (B) salinities, (C) soluble non-reactive phosphorus (SRP) and (D) chl a along Transects A and B during the summer (black bars) and winter (diagonal lines). No data: values below the detection limit of $0.10 \mu \mathrm{mol} \mathrm{l} \mathrm{l}^{-1}$. Stn B10 not sampled during the winter

\section{Bulk APA}

Surface APA ranged between 1.14 and $7.30 \mathrm{nmol}$ $\mathrm{l}^{-1} \mathrm{~h}^{-1}$ along Transects $\mathrm{A}$ and $\mathrm{B}$ during the summer (Fig. 4A). The highest APA value of $7.30 \mathrm{nmol} \mathrm{l}^{-1} \mathrm{~h}^{-1}$ was observed at Stn A1, and lowest was at Stn B6 $\left(1.14 \mathrm{nmol} \mathrm{l}^{-1} \mathrm{~h}^{-1}\right)$. Distribution of size-fractioned APA differed along Transects A and B ( $p<0.01)$ (Fig. 4B). Soluble APA $(<0.2 \mu \mathrm{m})$ contributed significantly (ca. 50 

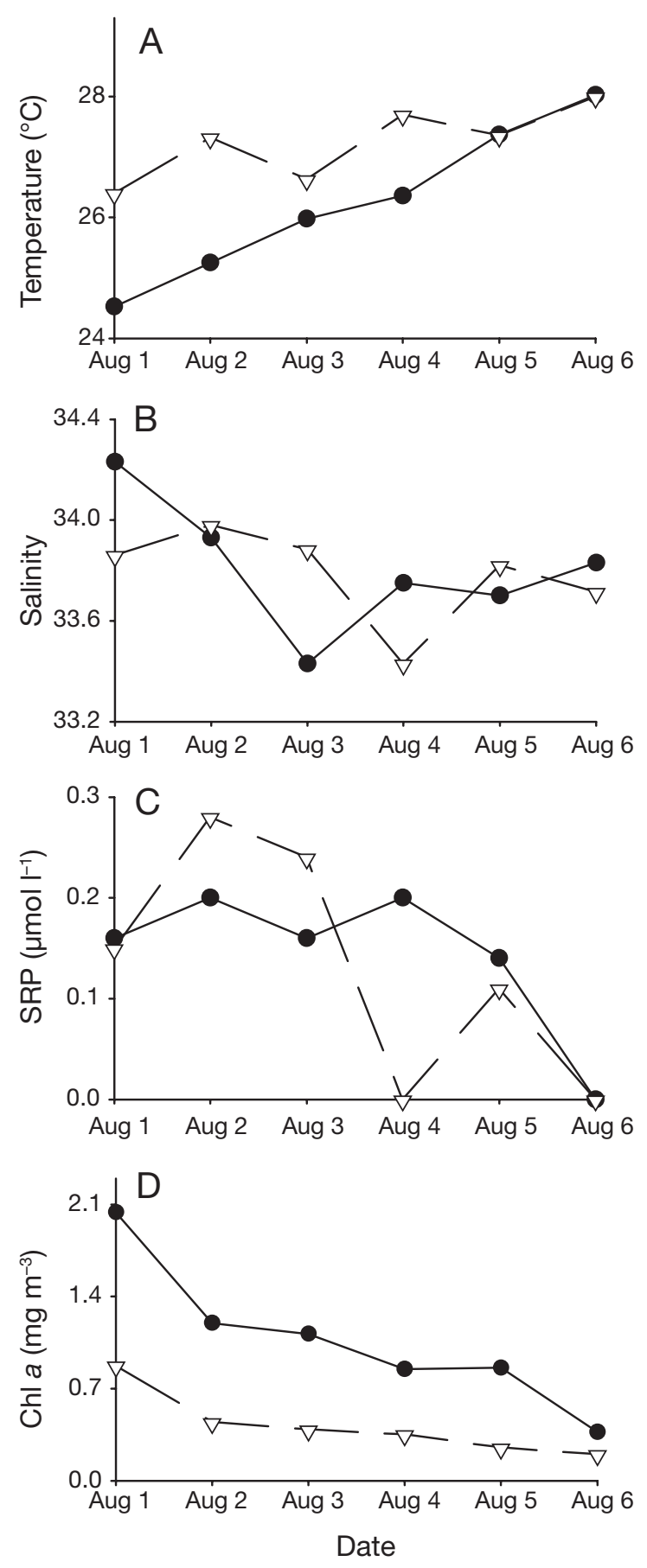

Fig. 3. Variations in (A) temperature, (B) salinity, (C) SRP and (D) chl $a$ in surface water during time-series investigations of Transect F during the summer. (๑) Stn F1; $(\Delta) \operatorname{Stn} F 3$

to $100 \%$ ) to the total bulk APA except at Stn B6. The range of 0.2 to $3 \mu \mathrm{m}$ (mainly bacteria) was measured at most of the stations (except Stns A3 and A10), with significant activity (approx. 40\%) detected at Stns B6 and B10. The fraction $>3 \mu \mathrm{m}$ (mainly phytoplankton) was detected at a total of 7 stations and contributed
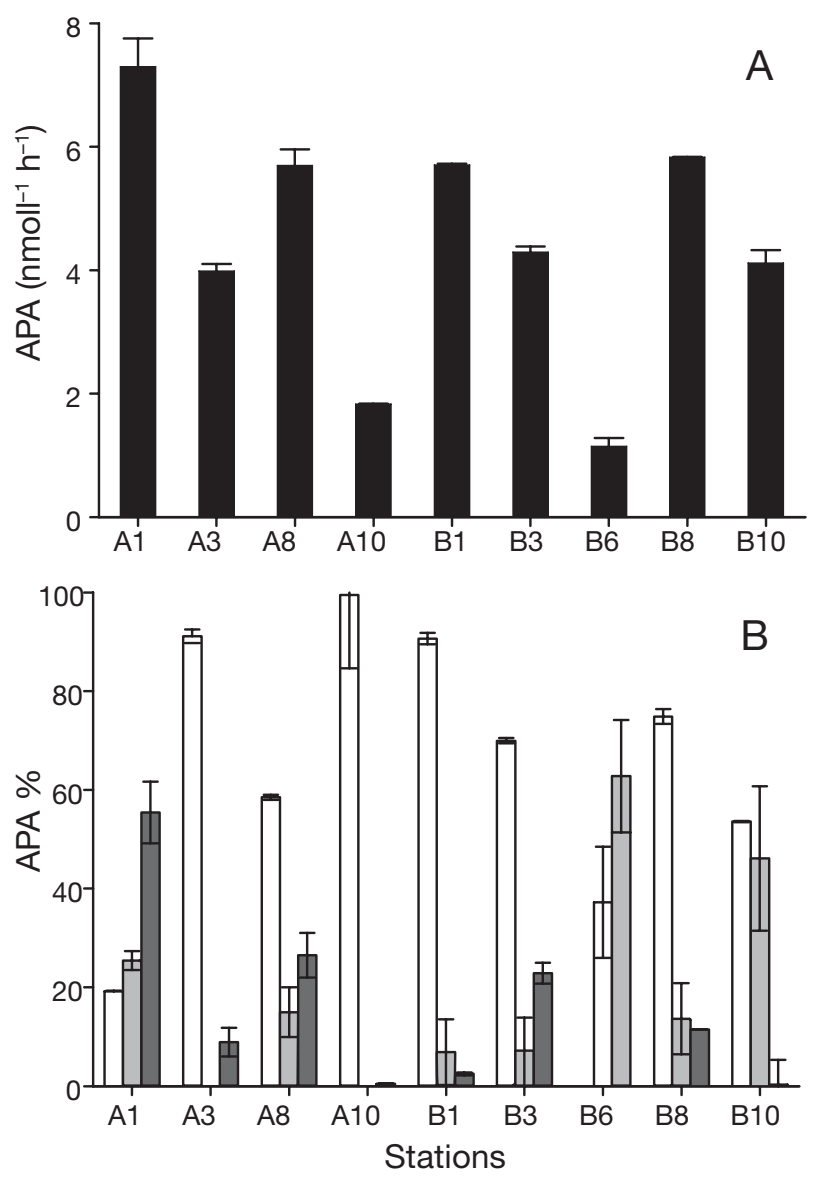

Fig. 4. Variations in (A) total alkaline phosphatase activity (APA) (mean $\pm 1 \mathrm{SD}, \mathrm{n}=2$ ) and (B) percent size-fractional APA contributions along Transects $\mathrm{A}$ and $\mathrm{B}$ during the summer. White bars: soluble APA $<0.2 \mu \mathrm{m}$; light grey bars: particulate $\mathrm{APA}=0.2$ to $3 \mu \mathrm{m}$ (mainly bacteria); dark grey bars: particulate APA $>3 \mu$ m (mainly phytoplankton) (mean $\pm 1 \mathrm{SD}, \mathrm{n}=2$ )

between 3 and $63 \%$ of the total APA, with a maximum of $63 \%$ recorded at Stn B6 where the highest chl a was determined. The total bulk APA showed no significant correlation to the environmental variables. However, particulate APA $>3 \mu \mathrm{m}$ was negatively correlated with temperature $(\mathrm{p}<0.05, \mathrm{n}=9)$ and DO $(\mathrm{p}<0.05, \mathrm{n}=9)$ and was positively correlated with DIN ( $p<0.01, n=9)$, reactive silicate $(\mathrm{p}=0.01, \mathrm{n}=9)$ and $\operatorname{TDP}(\mathrm{p}<0.05$, $\mathrm{n}=9$ ). A stepwise linear regression identified 3 significant variables for particulate APA $>3 \mu \mathrm{m}$ in decreasing order as DIN, DO and SRP with partial $\mathrm{r}^{2}$ values of $0.85,0.10$ and 0.03 , respectively.

Temporal variations of total bulk APA showed that APA generally increased during the time-series survey along Transect F (Fig. 5). Total APA was negatively correlated with SRP ( $\mathrm{p}<0.01, \mathrm{n}=19$ ), but positively correlated with DIN ( $\mathrm{p}<0.01, \mathrm{n}=19)$. Particulate APA $>3 \mu \mathrm{m}$ showed positive correlation with DIN/SRP 


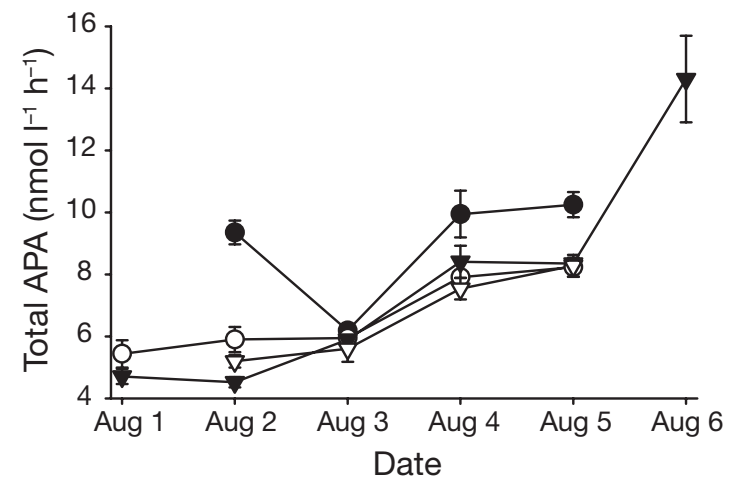

Fig. 5. Temporal variations in total APA along Transect $F$ during the summer. (•) Stn F0; (O) Stn F1; ( $)$ Stn F3; ( $\nabla)$ Stn F4

$(\mathrm{p}=0.01, \mathrm{n}=19)$, but negative correlation with $\mathrm{DO}$ $(\mathrm{p}<0.05, \mathrm{n}=19)$. A stepwise linear regression identified SRP as the significant variable for total bulk APA, although the $\mathrm{r}^{2}$ value was only 0.34 . As for particulate APA $>3 \mu \mathrm{m}$, the stepwise linear regression identified 3 significant variables in decreasing order of DIN/SRP, SRP and DIN with partial $r^{2}$ values of $0.57,0.14$ and 0.09 , respectively.

\section{Single-cell ELF labeling of phytoplankton}

During the summer, diatoms such as Skeletonema costatum, Asterionellopsis glacialis, Thalassionema nitzschioides, Chaetoceros spp. and Pseudo-nitzschia spp. dominated the phytoplankton community in the coastal waters of the Taiwan Strait, while the cyanobacterial Trichodesmium spp. dominated offshore waters (e.g. Stns A10 and B10). Dinoflagellates such as Protoperidinium spp., Prorocentrum spp., Ceratium spp., Gymnodinium spp. and others were also found in the study area. During the winter, however, phytoplankton biomass decreased significantly, and the dominant species were replaced by other diatoms such as Melosira sulcata and Coscinodiscus spp.

ELF staining was commonly observed for different species of diatoms, dinoflagellates and cyanobacteria. Table 1 shows ELF-labeled cells of different phytoplankton during the summer and winter. Dinoflagellates were more readily labeled with ELF during both seasons than were the diatoms. Percentages of ELF for species such as Coscinodiscus spp., Melosira sulcata, Thalassionema nitzschioides and Thalassiosira spp. decreased significantly during the winter compared

Table 1. Summary of phytoplankton taxa in the Taiwan Strait, and single-cell enzyme-labeled fluorescence (ELF) labeling during the summer and winter

\begin{tabular}{|c|c|c|c|c|c|c|}
\hline Taxa & $\begin{array}{l}\text { Cell- } \\
\text { labeled }\end{array}$ & $\begin{array}{l}\text { - Summer } \\
\text { Total } \\
\text { cell count }\end{array}$ & $\begin{array}{l}\text { ELF } \\
(\%)\end{array}$ & $\begin{array}{l}\text { Cell- } \\
\text { labeled }\end{array}$ & $\begin{array}{l}\text { - Winter - } \\
\text { Total } \\
\text { cell count }\end{array}$ & $\begin{array}{l}\text { ELF } \\
(\%)\end{array}$ \\
\hline \multicolumn{7}{|l|}{ Cyanophyceae } \\
\hline Trichodesmium erythraeum, T. thiebautii & 366 & 1856 & 19.7 & & & \\
\hline \multicolumn{7}{|l|}{ Dinophyceae } \\
\hline Alexandrium catenella, A. tamarense & 15 & 19 & 78.9 & & & \\
\hline Ceratium breve, $C$. fusus, $C$. trichoceros, $C$. tripos & 89 & 107 & 83.2 & 30 & 54 & 55.6 \\
\hline Dinophysis caudate, $D$. fortii & 8 & 13 & 61.5 & 63 & 130 & 48.5 \\
\hline Gymnodinium spp. & 46 & 54 & 85.2 & 62 & 70 & 88.6 \\
\hline Prorocentrum donghaiense, $P$. micans, $P$. sigmoides & 56 & 121 & 46.3 & 70 & 314 & 22.3 \\
\hline Protoperidinium depressum, $P$. oceanicum, $P$. pellucidum & 150 & 162 & 92.6 & 36 & 43 & 83.7 \\
\hline \multicolumn{7}{|l|}{ Bacillariophyceae } \\
\hline Actinocyclus ehrenbergii & & & & 14 & 192 & 7.3 \\
\hline Actinoptychus undulatus & & & & 5 & 96 & 5.2 \\
\hline Asterionellopsis glacialis & 474 & 1079 & 43.9 & & & \\
\hline $\begin{array}{l}\text { Chaetoceros affinis, C. curvisetus, C. debilis, C. densus, } \\
\text { C. laevis, C. pelagicus, C. pseudocurvisetus, C. weissflogii, etc }\end{array}$ & 74 & 1785 & 4.1 & 0 & 92 & 0 \\
\hline $\begin{array}{l}\text { Coscinodiscus asteromphalus, C. bipartitus, C. excentricus, } \\
\text { C. jonesianus, etc. }\end{array}$ & 84 & 162 & 51.9 & 30 & 744 & 4.0 \\
\hline Hemidiscus indicus, $H$. membranacus, $H$. sinensis & 5 & 45 & 11.1 & & & \\
\hline Lauderia borealis & 96 & 516 & 18.6 & & & \\
\hline Leptocylindrus danicus & 40 & 124 & 32.3 & & & \\
\hline Melosira sulcata & 30 & 373 & 8.0 & 44 & 2800 & 1.6 \\
\hline Pseudo-nitzschia delicatissima, P. pungens & 209 & 1036 & 20.2 & & & \\
\hline Rhizosolenia setigera, $R$. sinensis, $R$. stolterfothii, $R$. styliformis & $S 104$ & 178 & 58.4 & 43 & 68 & 63.2 \\
\hline Skeletonema costatum & 49 & 1631 & 3.0 & 0 & 23 & 0 \\
\hline Stephanopyxis palmeriana & & & & 6 & 119 & 5.0 \\
\hline Thalassionema nitzschioides & 576 & 1035 & 55.7 & 70 & 222 & 31.5 \\
\hline Thalassiosira rotula, T. subtilis & 34 & 86 & 39.5 & 14 & 80 & 17.5 \\
\hline Thalassiothrix frauenfeldii & 53 & 159 & 33.3 & & & \\
\hline
\end{tabular}


with the summer. However, percentages of ELF for most of the dinoflagellates, Rhizosolenia spp. and Skeletonema costatum did not change significantly between the 2 seasons. Percentages of ELF in the dominant species during the summer $(S$. costatum and Chaetoceros spp.) were very low, while $T$. nitzschioides, Asterionellopsis glacialis and Pseudo-nitzschia spp. were much higher. Some Trichodesmium spp. also had measurable ELF precipitates. In addition, percentages of Prorocentrum spp. and Dinophysis spp. were much lower compared to other dinoflagellates regardless of season.

Percentages of ELF-labeled cells along Transect $\mathrm{F}$ were much higher than those for Transects $A$ and $B$ during the summer. To further analyze single-cell APA during the time-series investigation, the dominant taxa i.e. Thalassionema nitzschioides, Pseudo-nitzschia pungens and Asterionellopsis glacialis, which had relatively high percentages of ELF labeling, were used to represent cellular APA variations at Stn F1. Results showed that percentages of all 3 species increased; this corresponded favorably with bulk APA (Fig. 6). At Stn F3, A. glacialis was one of the dominant species that was found throughout the time-series survey. A. glacialis showed a significant negative correlation with SRP $(\mathrm{p}<0.05)$ and positive correlation with bulk APA $(\mathrm{p}<0.01)$ (Table 2$)$.

\section{Variations in single-cell APA assay in batch culture}

The results from the confocal microscopy tests showed that nearly all sites of enzyme activity of Prorocentrum donghaiense and Skeletonema costatum were on the cell surface, while most phosphatase sites

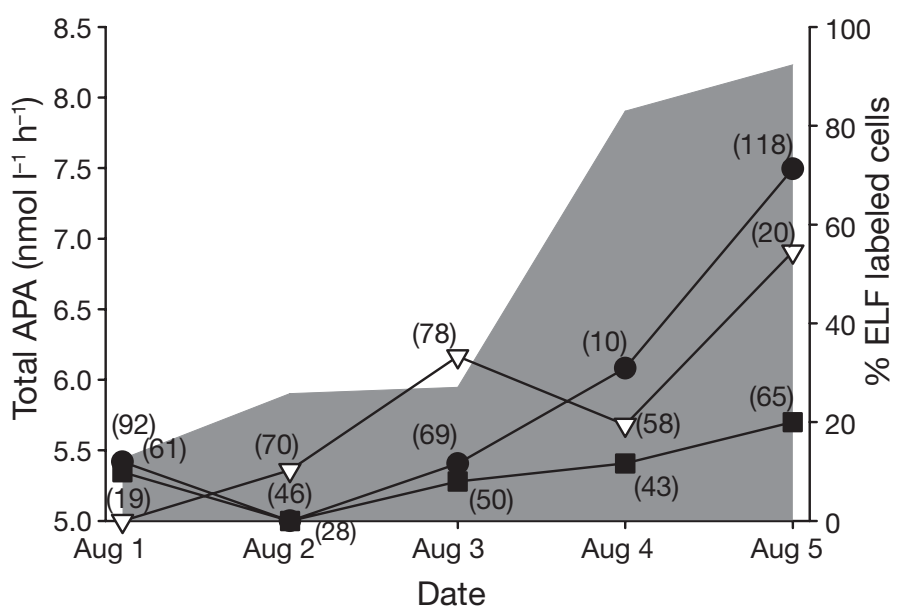

Fig. 6. Pseudo-nitzschia pungens, Thalassionema nitzschioides and Asterionellopsis glacialis. Total bulk APA with percent ELF-labeled cells at Stn F1. (৩) P. pungens; (O) T. nitzschioi$\operatorname{des}_{i}(\nabla)$ A. glacialis. Cell numbers counted in parentheses
Table 2. Asterionellopsis glacialis. Total bulk APA (nmol $\mathrm{l}^{-1}$ $\mathrm{h}^{-1}$ ) with percentage of ELF-labeled A. glacialis cells, total cell count and SRP $\left(\mu \mathrm{mol} \mathrm{l}{ }^{-1}\right)$ from time-series investigations at Stn F3 during the summer of 2004

\begin{tabular}{|c|c|c|c|c|c|c|}
\hline & Aug 1 & Aug 2 & Aug 3 & Aug 4 & Aug 5 & Aug 6 \\
\hline Bulk APA & 4.7 & 4.5 & 5.9 & 8.4 & 8.3 & 14.3 \\
\hline ELF-labeled \% & $\% \quad 0$ & 0 & 1.5 & 25.9 & 24.4 & 46.2 \\
\hline Cell no. & 164 & 135 & 122 & 185 & 229 & 45 \\
\hline SRP & 0.15 & 0.28 & 0.24 & $<0.1$ & 0.11 & $<0.1$ \\
\hline
\end{tabular}

of Alexandrium catenella were inside the cell. Table 3 shows APA variations of $P$. donghaiense, A. catenella, $S$. costatum and Asterionellopsis glacialis during the batch culture. At the beginning of the experiment, neither bulk APA nor ELF labeling could be detected for all 4 test species. Bulk APA in all test species increased with time. As for single-cell APA, significant ELF labeling was detected for all test species directly after 1 to $2 \mathrm{~d}$ of incubation. At the highest fluorescence, the whole cells were covered with ELF precipitates for all test species except $S$. costatum, which had only a few brightly fluorescing precipitates on the cell surface. ELF labeling could be detected for the 2 test dinoflagellates and the diatom A. glacialis throughout the study, but the intensity weakened with time. An interesting find was the significant ELF-labeling on the cell surface of $S$. costatum on Day 1, but within a few days,

Table 3. Prorocentrum donghaisense, Alexandrium catenella, Skeletonema costatum, Asterionellopsis glacialis. Bulk APA $\left(\mathrm{nmol} \mathrm{l}^{-1} \mathrm{~h}^{-1}\right)$ and ELF-labeled cells from the laboratory batch culture. (-) ELF fluorescence not on the cell; $(+)$ ELF fluorescence on $<10 \%$ of the cell surface; $(++)$ ELF fluorescence on 10 to $50 \%$ of the cell surface; (+++) ELF fluorescence on $>50 \%$ of the cell surface

\begin{tabular}{|c|c|c|c|c|c|c|}
\hline \multirow[t]{2}{*}{ Species } & \multirow[t]{2}{*}{ Day } & \multirow{2}{*}{$\begin{array}{l}\text { Bulk } \\
\text { APA }\end{array}$} & \multicolumn{4}{|c|}{ No. of ELF-labeled cells } \\
\hline & & & - & + & ++ & +++ \\
\hline \multirow[t]{4}{*}{ P. donghaisense } & 0 & 0 & 231 & & & \\
\hline & 1 & 1.66 & & 13 & 186 & 2 \\
\hline & 3 & 69.07 & & 5 & 24 & 186 \\
\hline & 5 & 149.83 & 16 & 22 & 163 & \\
\hline \multirow{4}{*}{ A. catenella } & 0 & 0 & 211 & 3 & & \\
\hline & 1 & 1.42 & & & 64 & 153 \\
\hline & 3 & 15.84 & & 5 & 25 & 170 \\
\hline & 5 & 165.55 & 1 & & 108 & 99 \\
\hline \multirow[t]{4}{*}{ S. costatum } & 0 & 0 & 218 & 1 & & \\
\hline & 1 & 2.30 & 35 & 7 & 184 & \\
\hline & 3 & 23.24 & 105 & 11 & 77 & \\
\hline & 5 & 178.23 & 230 & 3 & 14 & \\
\hline \multirow[t]{4}{*}{ A. glacialis } & 0 & 0 & 200 & & & \\
\hline & 1 & 0.12 & 220 & & & \\
\hline & 3 & 5.94 & 132 & 5 & 67 & 35 \\
\hline & 5 & 60.78 & 28 & 4 & 20 & 187 \\
\hline
\end{tabular}


abundant green precipitates had detached from the cell surface and were found in the medium.

The results indicate that alkaline phosphatase of the test phytoplankton species was induced under conditions of P-stress. APA characterization of Skeletonema costatum might be different from Prorocentrum donghaiense, Alexandriumcatenella and Asterionellopsis glacialis, since it would release the induced AP into the aqueous environment. Therefore, the absence of ELF precipitates on the surface of $S$. costatum cells did not signify lack of P-stress.

\section{DISCUSSION}

\section{Methodological consideration of bulk and single-cell ELF assay}

There have been several studies on bulk APA in open and coastal oceans, such as the central north Pacific (Perry 1972), central Atlantic Ocean (Vidal et al. 2003), Mediterranean Sea (Thingstad et al. 1998), southern Baltic Sea (Nausch 1998), northern Red Sea (Li et al. 1998, Stihl et al. 2001), north African upwelling region (Sebastián et al. 2004a,b) and the northern Gulf of Mexico (Ammerman \& Glover 2000). Unfortunately, there are 3 factors which make it impossible to compare our results directly with the values presented in other sources. First, the substrates used were different. By far the most widely used substrates are pnitrophenyl phosphate ( $\mathrm{p}-\mathrm{NPP})$, methyl-umbelliferryl phosphate (MUF) and 3-0-methylfluorescein phosphate (MFP). Sebastián et al. (2004b) summarized other research and concluded that different substrates would definitely influence kinetics of APA in natural waters. Second, different substrate concentrations were used. Our results showed that APA increased linearly with substrate concentration under low substrate concentration (0 to $8 \mu \mathrm{mol} \mathrm{l}^{-1} \mathrm{MFP}$ ). This was consistent with Healey \& Hendzel (1979), who promoted $10 \mu \mathrm{mol} \mathrm{l}^{-1} \mathrm{MFP}$ as the substrate concentration to achieve maximum phosphatase activity. Other authors advised the use of much lower substrate concentrations to increase sensitivity, due to the high background fluorescence of substrate (Perry 1972, Rose \& Axler 1998). Third, different incubation temperatures were used. Some authors used $35^{\circ} \mathrm{C}$ or $37^{\circ} \mathrm{C}$ for testing the maximum enzyme activities (Li et al. 1998, Stihl et al. 2001,Vidal et al. 2003), while others used the in situ temperatures to obtain factual APA values (Nausch 1998, Sebastián et al. 2004a,b). Therefore, in consideration of these factors, we can not reasonably compare our results with other values in the literature.

The bulk APA assay could indicate phytoplankton P-status in the general community, but it failed to pro- vide information on how different species might be responding to the nutrient environments (Dyhrman \& Palenik 1999). The results from bulk APA assays may be supported by the results of the single-cell ELF assay. Like other molecular techniques that probe in situ phytoplankton physiology, the technique of singlecell ELF labeling was developed to adequately diagnose P-stress in natural phytoplankton communities by directly assessing the cellular physiological status (González-Gil et al. 1998, Dyhrman et al. 2002). The ELF method makes it possible to determine which species within a natural phytoplankton community is or is not producing APA (González-Gil et al. 1998, Dyhrman \& Palenik 1999). However, this method is still in need of improvement.

In order to concentrate algal cells in the natural phytoplankton community, a 5 to $10 \mathrm{l}$ aliquot of natural water was strained through $10 \mu \mathrm{m}$ meshes. This procedure concentrated the cells sufficiently (at least the dominant micro-size and some nano-size species) to be studied statistically, but it also passed cells smaller than $10 \mu \mathrm{m}$. This was also an important aspect (even predominant in some offshore stations) in our study of biomass (data not presented). Due to the magnification limitations of microscopy in observing pico- and some nano-size phytoplankton, a further study using flow cytometry (FCM) should be conducted to better understand the P-status of the whole phytoplankton community using the single-cell ELF assay.

Bruckmeier et al. (2005) classified phosphatase by mode of expression (constitutive, inducible), celloriented activity (intracellular, extracelluar) or $\mathrm{pH}$ optimum. Inducible, extracellular alkaline phosphatase is deemed the typical characterization for most algae under P-stress (Cembella et al. 1984a, Dyhrman \& Palenik 1999, Hoppe 2003). However, some studies have shown the possible existence of constitutive phosphatase from the bulk APA assay (Gonzáles-Gil et al. 1998, Gillor et al. 2002, Sebastián et al. 2004a). Dyhrman \& Palenik (1999) advanced the concept that the ELF substrate could also label the intracellular AP and considered this kind of phosphatase a constitutive enzyme. Since the ELF method could not distinguish between inducible and constitutive $\mathrm{AP}$, the possibility of constitutive phosphatase might mislead the interpretation of ELF results. Fortunately, ELF labeling patterns to date have only detected inducible APA, with the exception of the cultured Alexandrium tamerense (Lomas et al. 2004). Results of our batch culture also showed that the intracellular phosphatase of A. catenella was inducible under P-stress. With this in mind, the presence of ELF-labeling in natural phytoplankton communities could be interpreted as an indication of P-stress. Diatoms such as Skeletonema costatum and Chaetoceros spp. showed low percentages of ELF 
labeling during the summer. It might not be safe to assume that these algae were not P-stressed. The laboratory incubation study showed that $S$. costatum was found to express AP into the water; however, other species are not likely to have this characteristic. Further study of phosphatase characterization of different species is, then, required since the APA distribution state might influence a cell's efficiency in obtaining available P (Thingstad et al. 1993). Therefore, the result of ELF-labeling might sometimes disguise the factual nutrient status of the phytoplankton. Besides, it is possible that if a particular species does not express APA (Dignum et al. 2004) or if its APA does not become labeled with ELF (Rengefors et al. 2001), it could be experiencing P-stress that is undetectable by current methods. We should, therefore, be cautious when using the ELF-labeling result to confirm whether a cell was P-stressed based on the ELF labeling result. To correctly and completely understand the P-status of different species in natural phytoplankton communities with the single-cell ELF assay, the single-cell APA characterization of at least the dominant species should be studied in the laboratory beforehand.

The single-cell ELF assay is still a qualitative assay in the field (González-Gil et al. 1998, Rengefors et al. 2003, Lomas et al. 2004). Therefore, further development i.e. epifluorescent microscopy equipped with an image analysis system or FCM is necessary to resolve this issue. The utilization of both the quantitative bulk APA and the qualitative single-cell APA assays might best provide comprehensive assessment of phytoplankton P-stress from community down to the individual taxon in natural phytoplankton communities.

\section{P-stress of phytoplankton in the Taiwan Strait}

Bulk APA results during the summer showed that APA ranged between 1.14 and $7.30 \mathrm{nmol} \mathrm{l}^{-1} \mathrm{~h}^{-1}$ along Transects A and B. The APA values along Transect F, in particular at Stn F0, were several times higher than those along Transects A and B, suggesting that P-stress in Transect $F$ was much more severe.

Inducement of AP is a common response of the phytoplankton community to P-stress (Healey \& Henzel 1979, Cembella et al. 1984a). AP is released to the aqueous environment through cell lysis or excretion, and its persistence exceeds the average generation time of most phytoplankton species (Li et al. 1998, Dyhrman et al. 1999); therefore, high APA (especially high soluble APA) may reflect P-stress of a phytoplankton community in the past (Li et al. 1998). In our study area, the percentages of 50 to $100 \%$ soluble APA in most of the stations might suggest phytoplankton were P-stressed for a longer time.
Although bulk APA data were lacking during the winter, the single-cell APA data showed some difference between the summer and winter. Percentages of ELF-labeled phytoplankton were lower during the winter, suggesting that the higher external SRP concentration had diminished phytoplankton P-stress during the winter. Percentages of ELF-labeled dinoflagellates were very high throughout the summer and winter, suggesting that these species were P-stressed in both seasons. Diatoms such as Coscinodiscus spp., Rhizosolenia spp. and Thalassionema nitzschioides etc., which had high percentages of ELF labeling, were also P-stressed during the summer. Although the percentages of Chaetoceros spp. and Skeletonema costatum were low during the summer, it would be unreasonable to suggest that these cells were not under P-stress. As we have found in the laboratory, S. costatum released abundant AP into the aqueous environment soon after phosphatase was induced. Therefore, 2 hypotheses might exist for species with low percentages of ELF labeling. First, they had a lower P requirement and were not P-stressed under the same conditions. Second, they were P-stressed, but they had unique AP characterization that could not be detected by the single-cell ELF assay in the field.

In our report, genus or family taxa were used as units to divide species generally. Significant differences existed among the different genera. Significant differences could also be found in individuals of the same genus, which meant there might be a difference in nutrient physiological status. For example, the percentage of ELF-labeled Chaetoceros weissflogii was as high as 80 to $90 \%$, while much lower percentages of ELF labeling were found in other Chaetoceros spp. during the summer. The percentages of Prorocentrum micans were lower than other Prorocentrum spp. These results indicated that different taxa, as well as different individual cells within the same species, experienced different degrees of P-stress under the same environmental conditions.

\section{Correlation between APA, P and other variables}

In our study, no significant correlations were observed between total bulk APA and the environmental parameters along Transects A and B. However, these factors might contribute in some way to phosphatase activity. An inverse relationship between APA and low ambient SRP concentration has been widely reported (Healey \& Henzel 1979, Cembella et al. 1984a, Annis \& Cook 2002). Although we found that the total bulk APA correlated significantly with SRP concentration during the time-series investigation along Transect $F$, the variable SRP could only explain 
$34 \%$ of the variation in total bulk APA. Besides, no significant correlation was observed between these properties along Transects A and B. Low phosphate concentrations are not necessarily accompanied by detectably high APA (Jansson et al. 1988, Hernández et al. 2002, Vidal et al. 2003). This might be due to an intracellular P pool or to a lag in the inducement or activation of enzyme synthesis (Perry 1972, Cembella et al. 1984a). Besides phosphate concentration, Hoppe (2003) suggested that several factors regulate phosphatase activity in the sea, including internal N:P ratios, allometric factors, individual $\mathrm{P}$ demand, substrate composition, SNP availability and recalcitrance. Single-cell APA results might also support the lack of significant correlation between bulk APA and SRP or SNP. Since the response threshold to P-stress and hence inducement capability of APA were different among species even in the same situation, community composition and abundance might also determine the final APA in an aquatic system.

Particulate APA $>3 \mu \mathrm{m}$ was mainly contributed by phytoplankton; thus we refer to this part of APA as 'phytoplankton APA'. A stepwise linear regression model: phytoplankton APA = DIN + DO + SRP showed that these 3 factors explained $98 \%$ of the variation of APA along Transects A and B. Another stepwise linear regression model: phytoplankton APA $=$ DIN/SRP + SRP + DIN also resulted in a high significance and explained $80 \%$ of the variability of phytoplankton APA along Transect F. SRP, DIN and DO were the most significant variables controlling the variation of phytoplankton APA in the study area. In contrast to phytoplankton APA, bacterial APA (mainly 0.2 to $3 \mu \mathrm{m}$ ) did not show significance with environmental variables $(p>0.05)$. These data meant that phytoplankton APA was more sensitive to influence by environmental variables than bacterial APA.

Bulk APA and single-cell APA compared favourably in indicating phytoplankton P-stress. The results showed that differences of single-cell APA existed within populations, indicating that individuals of different species or even the same species may experience different P-stress. This would depend on both the microenvironment surrounding them and their individual internal P-status. In both seasons, percentages of ELF labeling for dinoflagellates were higher than any for other groups (i.e. diatoms and cyanobacteria), suggesting that dinoflagellates suffer P-stress more easily. In addition, based on the singlecell APA data, dinoflagellates had the advantage over other phytoplankton in competing for SNP utilization, because dinoflagellates could induce more AP on the cell surface under P-stress.

In summary, bulk APA and single-cell ELF labeling compared favorably in this study of P-stress in the Taiwan Strait. Bulk APA showed that the phytoplankton community in the Taiwan Strait was under P-stress. High percentages of single-cell ELF labeling showed that the natural phytoplankton community, in particular the dinoflagellates, was under severe P-stress. The percentages of ELF-labeled representative phytoplankton species increased with bulk APA during the time-series investigation. Therefore, it is suggested that both protocols should be used together in order to provide comprehensive assessment of phytoplankton P-stress from community down to the species level in the natural phytoplankton community.

Although dinoflagellates displayed high ELF activity during both seasons, the biomass of dinoflagellates was low compared to diatoms. Thus, dinoflagellate APA might contribute little to bulk APA. The bulk APA value, in particular the high soluble APA, might indeed be related to bacteria or the P-stressed predominant diatoms such as Asterionellopsis glacialis, Pseudonitzschia spp. and Thalassionema nitzschioides.

Acknowledgements. The authors thank the captain and crews of RV 'Yan Ping 2', who made concerted efforts during sampling. We are grateful to Prof. W. Q. Ruan for his help during the cruise. We thank Prof. J. Hodgkiss of the University of Hong Kong for his comments on the manuscript. We are also grateful to the 3 anonymous reviewers for their helpful comments. This work was supported by grants from the China Natural Science Foundation (Nos. 40331004, 40576055, 40521003) and a 'Distinguished Talent of New Century' grant from the Ministry of Education to B. Q. Huang and was also partially funded by the National Basic Research Programme (Nos. 2001CB409704 and 2006CB400604).

\section{LITERATURE CITED}

Ammerman JW, Azam F (1991) Bacterial 5'-nucleotidase in aquatic ecosystems: a novel mechanism of phosphorus regeneration. Science 227: 1338-1340

Ammerman JW, Glover WB (2000) Continuous underway measurement of microbial ectoenzyme activities in aquatic ecosystems. Mar Ecol Prog Ser 201:1-12

Annis ER, Cook CB (2002) Alkaline phosphatase activity in symbiotic dinoflagellates (zooxanthellae) as a biological indicator of environmental phosphate exposure. Mar Ecol Prog Ser 245:11-20

Armstrong FAJ, Stearns CR, Strickand JDH (1967) The measurement of upwelling and subsequent biological processes by means of the Technicon AutoAnalyzer and associated equipment. Deep-Sea Res 14(3):381-389

Benitez-Nelson CR (2000) The biogeochemical cycling of phosphorus in marine systems. Earth Sci Rev 591:109-135

Bentzen E, Taylor WD, Millard ES (1992) The importance of dissolved organic phosphorus to phosphorus uptake by limnetic plankton. Limnol Oceanogr 37(2):217-231

Björkman K, Karl DM (1994) Bioavailability of inorganic and organic phosphorus compounds to natural assemblages of microorganisms in Hawaiian coastal waters. Mar Ecol Prog Ser 111:265-273

Bruckmeier B, Eisenmann H, Beisker W (2005) Exogenous alkaline phosphatase activity of algal cells determined by 
fluorometric and flow cytometic detection of soluble enzyme products (4-methyl-umbelliferone, fluorescein). J Phycol 41:993-999

Cembella AD, Antia NJ, Harrison PJ (1984a) The utilization of inorganic and organic phosphorous compounds as nutrients by eukaryotic microalgae: a multidisciplinary perspective, Part 1. CRC Crit Rev Microbiol 10(4): 317-391

Cembella AD, Antia NJ, Harrison PJ (1984b) The utilization of inorganic and organic phosphorous compounds as nutrients by eukaryotic microalgae: a multidisciplinary perspective, Part 2. CRC Crit Rev Microbiol 11(1):13-81

Dignum M, Hoogveld H, Matthijs HCP, Laanbroek HJ, Pel R (2004) Detecting the phosphate status of phytoplankton by enzyme-labelled fluorescence and flow cytometry. FEMS Microbiol Ecol 48:29-38

Dyhrman ST, Palenik B (1999) Phosphate stress in cultures and field populations of dinoflagellate Prorocentrum minimum detected by a single-cell alkaline phosphatase assay. Appl Environ Microbiol 65(7):3205-3212

Dyhrman ST, Webb EA, Anderson DM, Moffett JW, Waterbury JB (2002) Cell-specific detection of phosphorus stress in Trichodesmium from the Western North Atlantic. Limnol Oceanogr 47(6):1832-1836

Gillor O, Hadas O, Post AF, Belkin S (2002) Phosphorus bioavailability monitoring by a bioluminescent cyanobacterial sensor strain. J Phycol 38:107-115

González-Gil S, Keafer BA, Jovine RVM, Aguilera A, Lu SH, Anderson DM (1998) Detection and quantification of alkaline phosphatase in single cells of phosphorus-starved marine phytoplankton. Mar Ecol Prog Ser 164:21-35

Healey FP, Hendzel LL (1979) Fluorometric measurement of alkaline phosphatase activity in algae. Freshw Biol 9: 429-439

Hernández I, Niell FX, Whitton BA (2002) Phosphatase activity of benthic marine algae. An overview. J Appl Phycol 14: 475-487

Hong HS, Qiu SY, Ruan WQ, Hong GC (1991) MinnanTaiwan bank fishing ground upwelling ecosystem study. In: Hong HS, Qiu SY, Ruan WQ, Hong GC (eds) MinnanTaiwan bank fishing ground upwelling ecosystem study. Science Press, Beijing, p 1-18 (in Chinese with English abstract)

Hong HS, Huang BQ, Wang HL (1995) Phosphorus biogeochemistry in the Taiwan Strait and its adjacent waters. Proc Symp Marine Science in the Taiwan Strait and its adjacent waters, 12-15 Aug 1993, Xiamen. China Ocean Press, Beijing, p 289-295 (in Chinese with English Abstract)

Hoppe HG (2003) Phosphatase activity in the sea. Hydrobiologia 493:187-200

Huang BQ, Hong HS (1999) Alkaline phosphatase activity and utilization of dissolved organic phosphorus by algae in subtropical coastal waters. Mar Pollut Bull 39:205-211

Huang BQ, Ou LJ, Hong HS, Luo HW, Wang DZ (2005) Bioavailability of dissolved organic phosphorus compounds to typical harmful dinoflagellate Prorocentrum donghaiense Lu. Mar Pollut Bull 51:838-844

Jansson M (1976) Phosphatases in lake water: characterization of enzymes from phytoplankton and zooplankton by gel filtration. Science 194:320-321

Jansson M, Olsson H, Pettersson K (1988) Phosphatases: origin, characteristics and function in lakes. Hydrobiologia 170: 157-175

Karl DM, Yanagi K (1997) Partial characterization of the dissolved organic phosphorus pool in the oligotrophic North Pacific Ocean. Limnol Oceanogr 42(6):1398-1405
Krom MD, Kress N, Brenner S (1991) Phosphorus limitation of primary productivity in the eastern Mediterranean Sea. Limnol Oceanogr 36:424-432

Li H, Veldhuis MJW, Post AF (1998) Alkaline phosphatase activities among planktonic communities in the northern Red Sea. Mar Ecol Prog Ser 173:107-115

Liang HX (1997) Analysis of oceanographic condition in the Taiwan Strait during the summer 1994. In: Hong HS (ed) Oceanography in China, No. 7: Primary productivity and its controlling mechanism in Taiwan Strait regions. China Ocean Press, Beijing, p 48-61 (in Chinese with English abstract)

Lomas MW, Swain A, Shelton R, Ammerman JW (2004) Taxonomic variability of phosphorus stress in Sargasso Sea phytoplankton. Limnol Oceanogr 49(6):2303-2310

Menzel DW, Corwin N (1965) The measurement of total phosphorus in seawater based on the liberation of organically bound fractions by persulfate oxidation. Limnol Oceanogr 10:280-282

Michaels AF, Olson D, Sarmiento JL, Ammerman JW and 5 others (1996) Inputs, losses and transformations of nitrogen and phosphorus in the pelagic North Atlantic Ocean. Biogeochemistry 35:181-226

Murphy J, Riley JP (1962) A modified single solution method for determination of phosphate in natural waters. Anal Chim Acta 27:31-36

Nausch M (1998) Alkaline phosphatase activities and the relationship to inorganic phosphate in the Pomeranian Bight (southern Baltic Sea). Aquat Microb Ecol 16:87-94

Pai SC, Yang CC, Riley JP (1991) Effects of acidity and molybdate concentration on the kinetics of the formation of the phosphoantimonylmolybdenum blue complex. Anal Chim Acta 229:115-120

Parsons TR, Yoshiaki M, Lalli CM (1984) A manual of chemical and biological methods for seawater analysis. Pergamon Press, Oxford.

Perry MJ (1972) Alkaline phosphatase activity in subtropical central north Pacific waters using a sensitive fluorometric method. Mar Biol 15:113-119

Rengefors K, Pettersson K, Blenckner T, Anderson DM (2001) Species-specific alkaline phosphatase activity in freshwater spring phytoplankton: application of a novel method. J Plankton Res 23(4):435-443

Rengefors K, Ruttenberg KC, Haupert CL, Taylor C, Howes BL, Anderson DM (2003) Experimental investigation of taxon-specific response of alkaline phosphatase activity in natural freshwater phytoplankton. Limnol Oceanogr 48(3): $1167-1175$

Rose C, Axler RP (1998) Uses of alkaline phosphatase activity in evaluating phytoplankton community phosphorus deficiency. Hydrobiologia 361:145-156

Sañudo-Wilhelmy SA, Tovar-Sanchez A, Fu FX, Capone DG, Carpenter EJ, Hutchins DA (2004) The impact of surfaceadsorbed phosphorus on phytoplankton Redfield stoichiometry. Nature 432:897-901

Scanlan DJ, Silman NJ, Donald KM, Wilson WH, Carr NG, Joint I, Mann NH (1997) An immunological approach to detect phosphate stress in population and single cells of photosynthetic picoplankton. Appl Environ Microbiol 63(6): 2411-2420

Sebastián M, Arítegui J, Montero MF, Escanez J, Niell FX (2004a) Alkaline phosphatase activity and its relationship to inorganic phosphorus in the transition zone of the northwestern African upwelling system. Prog Oceanogr 62: 131-150

Sebastián M, Arístegui J, Montero MF, Niell FX (2004b) Kinetics of alkaline phosphatase activity, and effect of 
phosphate enrichment: a case study in the NW African upwelling region. Mar Ecol Prog Ser 270:1-13

Stihl A, Sommer U, Post A (2001) Alkaline phosphatase activities among populations of the colony-forming diazotrophic cyanobacterium Trichodesmium spp. (Cyanobacteria) in the Red Sea. J Phycol 37:310-317

Strickland JDH, Parson TR (1968). Determination of dissolved oxygen. In: Strickland JDH, Paarson TR (eds) A practical handbook of seawater analysis. Bull Fish Res Board Can 167:71-75

Thingstad TF, Skjoldal EF, Bohne RA (1993) Phosphorus cycling and algal-bacterial competition in Sandsfjord, western Norway. Mar Ecol Prog Ser 99:239-259

Thingstad TF, Zweifel UL, Rassoulzadegan F (1998) P limitation of heterotrophic bacteria and phytoplankton in the northwest Mediterranean. Limnol Oceanogr 43(1): $88-94$

Editorial responsibility: Howard Browman (Associate Editorin-Chief), Storebø, Norway
Thingstad TF, Krom MD, Mantoura RF, Flaten GAF and 15 others (2005) Nature of phosphorus limitation in the ultraoligotrophic eastern Mediterranean. Science 309: 1068-1071

Vidal M, Duarte CM, Agusti S, Gasol JM, Vaqué D (2003) Alkaline phosphatase activities in the central Atlantic Ocean indicate large areas with phosphorus deficiency. Mar Ecol Prog Ser 262:43-53

Wu J, Sunda W, Boyle EA, Karl DM (2000) Phosphate depletion in the western North Atlantic Ocean. Science 289:759-762

Wu LY, Ruan WQ, Chen R (1997) The geochemical behavior of phosphorus in the Taiwan Strait. II. The supplementation and cycle of phosphorus. In: Hong HS (eds) Oceanography in China. No. 7. Primary productivity and its controlling mechanism in Taiwan Strait regions. China Ocean Press, Beijing, p 107-114 (in Chinese with English abstract)

Submitted: February 24, 2006; Accepted: May 28, 2006 Proofs received from author(s): November 20, 2006 